\title{
REVIEW \\ Hormone involvement in the establishment of \\ pregnancy
}

\author{
M. J. Sauer \\ Ministry of Agriculture, Fisheries and Food, Cattle Breeding Centre, Shinfield, \\ Reading RG2 9BZ, U.K.
}

\section{Introduction}

The capacity of the conceptus to synthesize a variety of hormones has been established for many years (Klopper \& Diczfalusy, 1969; Davies \& Ryan, 1972; Fuchs \& Klopper, 1977). It has been demonstrated that the embryo is able to influence maternal functions before and during the implantation or attachment period (De Feo, 1967; Heald, 1976; Perry, Heap, Burton \& Gadsby, 1976) although the means by which it secures its continued existence and development at this time are only now becoming clear. The objective of this review is to discuss aspects of embryonic and uterine development during the pre- and peri-implantation period in relation to the hormonal exchanges believed to occur at this time. The main emphasis is placed on embryonic hormones, particularly steroids, in relation to the influence of hormones on preimplantation embryonic development, maternal recognition of pregnancy and hormonal involvement in the implantation process.

\section{Steroid metabolism by the preimplantation embryo and the influence of hormones}

Before implantation the embryo is dependent on oviductal and uterine secretions (the histotrophe) for nutrition and devalopment, particularly in animals in which blastocyst expansion and development precede implantation, e.g. pigs, sheep, cows and, to a lesser extent, rabbits. By contrast, the mouse embryo can be cultured to the blastocyst stage in comparatively simple chemically defined media (Biggers, 1971). The culture of bovine embryos to the blastocyst stage has only been possible in media based on oviductal (Tervit, Whittingham \& Rowson, 1972) or ovarian follicular (Renard \& du Mesnil du Buisson, 1976) fluid constituents.

The first differentiative event during embryogenesis is the polarization of individual blastomeres into trophoblast and the inner cell mass. The fate of individual blastomeres appears to be determined by their relative 'inside-outside' location at this time (but see Denker, 1976, for a recent review) rather than through the direct influence of maternal factors. Although the embryo would not appear to require exogenous hormonal stimuli for development up to the blastocyst stage in vitro, maternal steroids have been shown to regulate genital tract secretions in vivo (Surani, 1977) and could by this means exert an influence on the developing embryo. Embryonic development beyond the unilaminar blastocyst stage does not normally proceed until the blastocyst has freed itself from the zona pellucida (McLaren, 1974). The mechanism by which the shedding of the zona pellucida is regulated is not fully understood but apparently involves the action of proteolytic enzymes arising from the endometrium (McLaren, 1970; Mintz, 1971 \& 1972; Notides, Hamilton \& Rudolph, 1973; Pinsker, Sacco \& Mintz, 1974; Joshi \& Murray, 1974; Rosenfeld \& Joshi, 1977). These enzymes seem to be controlled by the ovarian steroids (Dickmann, 1972; Surani, 1975). Proteolytic activity derived from the blastocyst itself 
may also be involved in the process of lysis and this activity has been implicated in the initiation of implantation (Dickmann, 1969; Owers \& Blandau, 1971; Denker, 1972; Andary, Dabich \& Van Winkle, 1972; Pinsker et al., 1974; Rosenfeld \& Joshi, 1977). In animals in which delayed implantation occurs (e.g. roe deer and lactating rat), zona loss is delayed and hatching without lysis may take place (Renfree, 1976; Enders \& Given, 1977). A similar process is thought to occur during culture in vitro (McLaren, 1974).

Steroid hormones have been shown to control cell division and the synthesis of specific proteins in particular circumstances (King \& Mainwaring, 1973; King \& Thompson, 1974; Baulieu et al., 1975) and it has been suggested that they may thus govern early embryonic development. Steroids synthesized by the embryo itself may be involved in regulating the transformation of morula to blastocyst and in zona loss. This view is based largely on the establishment, using histochemical techniques, of a temporal association between these events and the development of enzyme activity essential for the transformation of neutral steroid precursors into active hormones (namely the $\Delta^{5}-3 \beta$-hydroxysteroid and oestradiol-17 $\beta$-hydroxysteroid dehydrogenases). Steroid-metabolizing enzymes have been demonstrated by histochemical techniques in the preimplantation embryo of several species (mouse: Dey \& Dickmann, 1974a; rat: Dey \& Dickmann, 1974b, c; Dickmann \& Dey, 1974a, b, c; hamster: Dickmann \& Sen Gupta, 1974; rabbit: Dickmann, Dey \& Sen Gupta, 1975a, b). Enzyme activity was not detected in pre-morula stages but was maximal in blastocysts and declined rapidly before disappearing shortly after implantation (Dickmann et al., 1976). In contrast, Nimura \& Ishida (1976) were able to detect enzyme activity of similar intensity at all stages of development in both fertilized and unfertilized hamster ova, suggesting that the onset of histochemically demonstrable steroid enzyme activity is not specifically associated with a particular developmental stage.

When biochemical methods are used to demonstrate steroidogenesis a different picture emerges. Steroid-metabolizing enzymes were not detected in mouse morulae or blastocysts by radioimmunoassay (Chew \& Sherman, 1975; Sherman \& Atienza, 1977) or chromatographic (Chew \& Sherman, 1975; Sherman \& Atienza, 1977; Antila, Koskinen, Niemala \& Saure, 1977) methods to quantitate the transformed products. A variety of substrates were used including pregnenelone, progesterone, androstenedione and dehydroepiandrosterone. In the rabbit preimplantation blastocyst, however, steroid-metabolizing enzymes were demonstrated by Huff \& Eik-Nes (1966) and by George \& Wilson (1978). The latter specifically demonstrated the ability of the embryo to synthesize androgens and oestradiol around the period of implantation. The disparity between the results obtained from the mouse and the rabbit using biochemical assay procedures may be due to differences in their relative developmental stages before implantation. The contrasting results obtained for mouse embryos with histochemical and biochemical techniques is disconcerting, although histochemical detection of steroid metabolizing enzymes does not necessarily indicate that steroidogenesis is taking place. Levy, Deane \& Rubin (1959) demonstrated steroid-metabolizing enzymes in the oviductal epithelium of the rat, a tissue not normally associated with steroid metabolism, suggesting the presence of non-specific dehydrogenases capable of acting on hydroxysteroids. In the histochemical and biochemical approaches substrate levels far in excess of anticipated physiological levels were used, and differences between incubation period, culture medium and atmosphere (Whitten, 1971) may have contributed to the variations found.

The anti-oestrogen CI-628 has been shown to block the development of the mouse preimplantation embryo in vitro and this has been used to argue that oestradiol influences embryo development directly (Dickmann et al., 1976; Sen Gupta, Dey \& Dickmann, 1977). Although some workers have shown that oestradiol induces increased synthesis of protein, RNA and DNA in the embryo (Smith \& Smith, 1971; Harrer \& Lee, 1973), others have failed to show any direct influence of exogenous steroid hormones in vitro (Psychoyos, 1973; Weitlauf, 1976; Warner \& Tollefson, 1977). Blastocyst development and subsequent zona loss in vitro appear to 
be controlled only indirectly by maternal steroid hormones, probably through the secretions of the oviductal and endometrial epithelia (Mintz, 1971; McLaren, 1973; Pinsker et al., 1974; Surani, 1975, 1977; Weitlauf, 1976; Aitken, 1977; Borland, Erickson \& Ducibella, 1977; Stone \& Hamner, 1977; Stone, Richardson, Hamner \& Oliphant, 1977). The independence of the embryo from the influence of steroid hormones when grown in extra-uterine sites (Dickmann, 1969) or in culture (Biggers, 1971; Whittingham, 1971) lends weight to the existence of an endogenous control mechanism.

\section{Maternal recognition of pregnancy}

In mammals the maintenance of an active corpus luteum is generally essential for the continuation of pregnancy since the prolonged secretion of progesterone is required to maintain myometrial quiescence and endometrial receptivity. The corpus luteum is developed and maintained under the influence of luteotrophic hormone(s). Regression may be due to the action of a luteolysin, which has been shown to be prostaglandin (PG) F-2 $\alpha$ in some species. During pregnancy the conceptus could effect luteal maintenance directly by secretion of a luteotrophin or an anti-luteolysin or act indirectly at the uterine or ovarian level. The active agent might also be synthesized by the uterus following a suitable stimulus from the conceptus.

Embryonic involvement in luteal maintenance is confounded in species which develop decidual placentae (e.g. rat, mouse and man). In the rat it has been demonstrated that the decidual cells themselves have a luteotrophic action (Wilson, Butcher \& Inskeep, 1970; Castracane \& Shaikh, 1976). Similarly, species in which pseudopregnancy can be induced (e.g. rat, mouse and hamster) experience a period of luteal induction and maintenance as a result of the release of pituitary luteotrophin stimulated by mating (Watson, Anderson, Alam, O'Grady \& Heald, 1975; Nalbandov, 1976). Experiments designed to exclude extra-embryonic influences in the rat have indicated that the embryo may also have a direct luteotrophic action (Chatterton, MacDonald \& Ward, 1975).

Embryonic luteotrophin (e.g. human chorionic gonadotrophin, hCG) can be detected from as early as Days 6-10 in primates (Wide, 1969; Kosasa, Levesque, Goldstein \& Taymor, 1973; Saxena, Hasan, Haour \& Schmidt-Gollwitzer, 1974; Hogden et al., 1976) but a macromolecular luteotrophin has not been identified in the cow, pig or sheep. Early work by Rowson \& Moor (1967) indicated that homogenates of Day 14-15 sheep conceptuses contained a heat-labile substance capable of extending luteal function following repeated intrauterine infusion commencing on Day 12 of pregnancy. The active substance does not appear to be placental lactogen because Martal \& Djiane (1977) were unable to detect lactogen in ovine trophoblast before Days 16-17 of pregnancy and could not demonstrate an extension of corpus luteum life-span when purified ovine placental lactogen was similarly infused in the uteri of sheep. Martal, Lacroix, Loudes, Saunier \& Wintenberger-Torrès (1979) have identified an antiluteolytic component from trophoblasts at Days 14-16 of pregnancy and termed it "trophoblastin". The maintenance of progesterone secretion rather than the presence of a luteotrophin or antiluteolysin is the earliest physiological manifestation of pregnancy so far detected in the cow (Shemesh, Ayalon \& Lindner, 1968), sheep (Bassett, Oxborrow, Smith \& Thorburn, 1969; Stabenfeldt, Drost \& Franti, 1972) or pig (Robertson \& Sarda, 1971). Embryo-specific antigens have, however, been found in the maternal circulation of some farm animals (Cerini, Cerini, Findlay \& Lawson, 1976; Cerini, Findlay \& Lawson, 1976; Staples, Lawson, Cerini, Sheers \& Findlay, 1976) from a very early stage of embryo development (apparently Day 6 in the sheep: Cerini et al., 1976), although these need not be responsible for the luteotrophic effect. A pregnancyspecific protein has also been detected in the endometrium and in uterine flushings from cows bearing blastocysts 15 days after service (Laster, 1977). 
In order to prevent cyclic luteolysis in the pig, pregnancy recognition must occur by Days $10-$ 12 (Dhindsa \& Dziuk, 1968). Administration of exogenous oestradiol at this time can have a luteotrophic effect both in vivo (Gardner, First \& Casida, 1963) and in vitro (Goldenberg, Bridson \& Kohler, 1972). It has been proposed that oestrone is synthesized and secreted by the pig blastocyst from as early as Day 12 of pregnancy, and is subsequently sulphated in the endometrium, transported to the ovary and there hydrolysed back to active oestrone; embryonic oestrone may thus provide a luteotrophic stimulus (Perry \& Heap, 1973; Perry, Heap \& Amoroso, 1973; Heap \& Perry, 1974; Heap, Perry, Gadsby \& Burton, 1975; Perry et al., 1976; Van der Wiel \& Everts, 1977). Steroid metabolism (aromatase, 17 $\beta$-oxidoreductase and 3 sulphatase activity) has been demonstrated in vitro, indicating the capacity of the pig conceptus to synthesize oestrogen at an early stage. This is consistent with the high levels of oestrogens found in blastocyst tissue (Van der Wiel \& Everts, 1977) and with histochemical evidence for steroid metabolism in the trophoblast (Flood, 1974) during this period. Systemic levels of oestrone sulphate have been shown to increase from Day 16 onwards (Robertson \& King, 1974). Bazer \& Thatcher (1977) have suggested that porcine embryonic oestrogens may provide an antiluteolytic influence by redirecting uterine prostaglandin $F$ secretion from the uterine vein into the uterine lumen.

Histochemical evidence (Flood \& Marrable, 1975) indicates that the equine embryo may also be capable of limited steroid metabolism from Day 13 onwards. Preliminary in-vitro studies with sheep (Gadsby, Burton, Heap \& Perry, 1976) and cattle (Gadsby et al., 1976; Shemesh, Milaguir, Ayalon \& Hansel, 1979) conceptuses have failed to reveal a potential to synthesize oestrogens in a period when they possess the ability to maintain luteal function, as demonstrated by embryo transfer experiments (Moor \& Rowson, 1966; Betteridge, Mitchell, Eaglesome \& Randall, 1976). For this reason a luteotrophic or antiluteolytic mechanism similar to that proposed for the pig does not seem likely in these species.

The maintenance of luteal activity in the pregnant ewe relies, at least in part, on the local relationship existing between the gravid horn and adjacent ovary (Moor \& Rowson, 1966; Mapletoft, Del Campo \& Ginther, 1975). The embryo may effect humoral release of luteotrophin via the uterus (Mapletoft et al., 1975; Mapletoft, Lapin \& Ginther, 1976) or inhibit uterine synthesis, release or transport of the presumptive luteolysin, PGF-2 $\alpha$ (see Flint \& Hillier, 1975; Henderson \& McNatty, 1975). Thorburn, Cox, Currie, Restall \& Schneider (1973) have shown that in early pregnancy surges in utero-ovarian venous PGF levels were either absent on Days $12-16$ or were very much reduced relative to the levels observed at similar times in the non-pregnant cycle. These findings are not supported by other workers who obtained no significant reduction in PGF levels in uterine venous blood or endometrium when pregnant and non-pregnant animals were compared (Wilson et al., 1972; Pexton, Weems \& Inskeep, 1975).

Although uterine venous and ovarian arterial levels of PGE have not been measured, the observation that PGE-2 may antagonize the luteolytic action of PGF- $2 \alpha$ in vivo suggests that PGE-2 may be a potential uterine antiluteolysin (Henderson, Scaramuzzi \& Baird, 1977; Pratt, Butcher \& Inskeep, 1977). Shemesh et al. (1979) have shown that PGE synthesis can be induced in Day 13-14 cow conceptuses.

There is considerable evidence that the rabbit conceptus is capable of synthesizing an hCGlike gonadotrophin at an early stage of development. Whether secretion occurs before or after implantation, however, remains the subject of controversy (Fuchs \& Beling, 1974; Haour \& Saxena, 1974; Fujimoto, Enker, Reigle, \& Dukelow, 1975; Fujimoto \& Tanaka, 1975; Sundaram, Connel \& Passantino, 1975; Holt, Heise, Wilson \& Keyes, 1976; Ellinwood, Siedel \& Niswender, 1977; Singh \& Adams, 1978). Evidence for the production of gonadotrophin by mouse embryos before implantation has also been presented (Wiley, 1974; Anon, 1975). Maternal uptake would be facilitated by the increased uterine vascular permeability known to occur before implantation (Psychoyos, 1960; Finn \& McLaren, 1967; Boshier, 1970). Maternal recognition (Table 1) precedes attachment in certain farm animals and it seems likely, therefore, 
that luteotrophin released by the conceptus should be detectable before the earliest signs of attachment can be demonstrated. If a luteotrophin is produced by the conceptus it would be of particular social and economic significance in man and farm animals for which early determination of pregnancy is often desirable. The nature of the embryonic luteotrophic influence has not yet been determined, but Morton, Nancarrow, Scaramuzzi, Evison \& Clunie (1979) have claimed that there is an immunological difference between pregnant and nonpregnant sheep which can be detected $24 \mathrm{~h}$ after mating. Very early detection of pregnancy would offer advantages for artificial insemination in cattle over the current milk progesterone method since repeat inseminations would be possible at the first oestrus after the initial service.

Table 1. Comparison of stage of maternal recognition and attachment in farm animals

\begin{tabular}{lcl} 
Species & $\begin{array}{c}\text { Day by which embryo must be present for } \\
\text { luteal maintenance }\end{array}$ & Day of earliest attachment \\
\hline Pig & $\begin{array}{c}\text { Days 10-12 (Dhindsa \& } \\
\text { Dziuk, 1968)* }\end{array}$ & Day 13 (Crombie, 1970) \\
Cow & $\begin{array}{c}\text { Day 16 (Betteridge } \text { et al., 1976) } \dagger \\
\text { Sheep }\end{array}$ & Days 12-13 (Moor \& Rowson, 1966) $\dagger$ \\
\hline
\end{tabular}

* Determined by destruction or removal of embryo.

$\dagger$ Determined by synchronous embryo transfer.

\section{Hormonal involvement in implantation}

It would seem necessary at this stage to define implantation since gross morphological differences exist between modes of implantation in different species (Wimsatt, 1975; Enders, 1976). The start of implantation may be defined as the period at which it is possible to distinguish differences between those areas of the uterus which do or do not contain a blastocyst. In rodents, implantation characteristically involves erosion of the uterine epithelium and invasion and decidualization of the stroma, the blastocyst finally becoming embedded in the uterine wall. By contrast, in the pig, sheep, cow and horse, contact between the conceptus and uterus remains superficial, forming essentially an epitheliochorial placenta (Boshier, 1969; Björkman, 1970), although in the sheep the placenta has been termed syndesmochorial (Davies \& Wimsatt, 1966). Implantation in sheep initially involves the formation of interdigitating microvilli but subsequently placental development is dependent on the formation of chorionic villi. In these circumstances, there is no direct contact between trophoblast and endometrial stroma and stromal decidualization does not occur. This mode of implantation will therefore be referred to as attachment.

\section{Ovarian hormones}

The mechanism of implantation has been studied in detail in the rat and mouse and the subject has been much reviewed (Marcus \& Shelesnyak, 1970; Psychoyos, 1973; Glasser \& Clark, 1975; Yochim, 1975; Heald, 1976; Finn, 1977). In all mammals studied progesterone is essential for the maintenance of early pregnancy and in most species it is also a pre-requisite for implantation (Davies \& Ryan, 1972); the guinea-pig (Deanesly, 1960) and the armadillo (Buchanon, Enders \& Talmage, 1956) are two notable exceptions to the latter. In the rat and mouse post-ovulatory oestrogen is also required since it is necessary to achieve an endometrial status conducive both to implantation and normal blastocyst development (Surani, 1977). In these species blastocyst implantation is accompanied by the transformation of endometrial stromal cells into decidual cells (De Feo, 1967). It is thought that stromal cells must first undergo 
a "re-programming" mitotic cycle (Finn \& Martin, 1974; Heald, 1976) under the influence of ovarian oestrogen acting on a progesterone-dominated uterus (Psychoyos, 1966). This sequence gives rise to sensitized stromal cells which are only then capable of responding to the decidualizing stimulus of the blastocyst. This period of receptivity occurs over a well defined but limited period after ovulation and is characteristic for each species (Finn \& Porter, 1975a). Before this period, oviductal and endometrial secretions actively inhibit the invasive activity of the trophoblast (Nillson, 1970). Indeed, the embryo can implant at various ectopic sites when experimentally transferred from the uterus (Fawcett, Wislocki \& Waldo, 1947; Kirby, 1963a, b; Samuel, 1971). Uterine secretions can be toxic to the embryo if there is a lack of synchrony between its developmental stage and that of the uterus (Chang, 1950; Noyes \& Dickmann, 1960; Noyes, Dickmann, Doyle \& Gates, 1963; Rowson \& Moor, 1966, Moor, 1968; Rowson, Lawson, Moor \& Baker, 1972). The nature of the barrier to implantation is not understood although it may well be associated with the uterine epithelium since implantation may occur in the uterus at oestrus if the epithelium is damaged (see Cowell, 1969; Samuel, 1971; Finn, 1977). It may therefore be inferred that the process of implantation is initially dependent upon the elaboration of a 'permissive' endometrium rather than the inherent invasive properties of the trophoblast (Glasser \& Clark, 1975; Yochim, 1975). At the appropriate time the epithelium presumably ceases to inhibit trophoblast invasion, enabling implantation and embryo development to continue. Endometrial differentiation must pass through a critical stage since the uterus selectively accepts only synchronized blastocysts during transplantation experiments. If the appropriate decidualizing stimulus is not forthcoming during this period the sensitized stromal cells rapidly lose their capacity to respond (De Feo, 1967). Whether "programmed cell death" ensues in these few sensitized stromal cells or in the epithelial cells which presumably mediate the decidualizing stimulus is uncertain (Finn \& Martin, 1974).

Although it is established that both post-ovulatory ovarian oestrogen and progesterone are pre-requisites for implantation in the rat and mouse (Psychoyos, 1973) and that preovulatory oestrogen probably plays a role in potentiating their influence (Finn \& Martin, 1970), a requirement for post-ovulatory oestrogen in the implantation or attachment process in other species has not been established. Implantation may occur in the presence of progesterone alone. This has been demonstrated by ovariectomy and hormone replacement therapy soon after mating in a variety of species including rabbit, guinea-pig and hamster (see Marcus \& Shelesnyak, 1970) monkey (Meyer, Wolf \& Arslan, 1969), sheep (Foote, Gooch, Pope \& Cassida, 1957; Moor \& Rowson, 1959; Bindon, 1971; Sarda, Robertson \& Smeaton, 1973; Cumming, Baxter \& Lawson, 1974), cow (Hawk, Brinsfield, Turner, Whitmore \& Norcross, 1963) and pig (Gentry, Anderson \& Melampy, 1973). This does not, however, exclude the involvement of oestrogens from the normal process since they may still exhibit a limited synergistic effect with progesterone. Unfortunately, few studies of blood or uterine levels of these hormones have been undertaken following ovariectomy. It is only in the rat and mouse that extra-ovarian sources of oestrogen have been investigated to any extent (Psychoyos, 1973) and the possibility exists that the preimplantation embryo may be capable of synthesizing or accumulating oestrogen (Dickmann et al., 1976).

\section{The interaction between embryo and endometrium at implantation}

One of the earliest endometrial responses to the presence of the blastocyst is a dramatic increase in vascular permeability limited to the locality of the rat blastocyst (Psychoyos, 1960). Since this response only occurs naturally at the time of maximum sensitivity to decidual induction and since the permeability reaction is thought to be an immediate pre-requisite for the decidual cell reaction and implantation (Yochim, 1975), it has been used to assess deciduogenic stimuli and the timing of implantation initiation. The permeability changes allow dyes such as Geigy blue or Pontamine blue (effectively of high molecular weight) to effuse rapidly from 
localized implantation sites following intravenous injection, making the onset of implantation readily apparent. This dye reaction is especially marked in rodents such as the rat and mouse (Psychoyos, 1960; Finn \& McLaren, 1967) in which definitive implantation occurs, but has also been used to assess the initial stages of attachment in the sheep (Boshier, 1970). Despite species differences in the mode of implantation or attachment it has been suggested that the nature of the implantation or attachment stimulus may well be similar in a number of species, although the endometrial response produced may vary considerably (Finn \& Porter, 1975b). No direct evidence is yet available to indicate the nature of the blastocyst stimulus assumed to initiate the vascular permeability changes, subsequent decidual cell formation and implantation.

The concept of histamine involvement in the permeability changes described above has been discussed (Shelesnyak, 1954, 1957) but has not gained general acceptance (De Feo, 1967; Tachi, Tachi \& Lindner, 1970; Finn \& Porter, 1975c). Recent work by Brandon \& Wallis (1977) has, however, overcome the major objections and demonstrated that inhibition of implantation and the vascular permeability reaction can be achieved by the combined systemic administration of histamine $\mathrm{H}_{1}-$ and $\mathrm{H}_{2}$-receptor antagonists. Prostaglandins are also associated with the inflammatory response (Vane, 1976) and their synthesis is directly inhibited by aspirin or indomethacin which may exert their anti-inflammatory action in this way (Flower, 1974). The decidual response and vascular permeability reaction can be inhibited by indomethacin treatment by intrauterine infusion (Tobert, 1976) or subcutaneous injection (Castracane, Saksena \& Shaikh, 1974; Kennedy, 1976; Saksena, Lau \& Chang, 1976; Hoffman, 1977; Kennedy, 1977). The effect of the latter treatment was prevented by subsequent intraperitoneal injection of PGF-2 $\alpha$ combined with histamine (Saksena et al., 1976). Decidualization may be induced in the immature rat by the intraluminal introduction of PGF- $\alpha$ (Sananes, Baulieu $\&$ Goascogne, 1976) and in the rabbit by the insertion of intrauterine implants of PGF-2 $\alpha$ and PGE-2 (Hoffman, Strong, Davenport \& Fröhlich, 1977). The similar influence of PGE-2 and PGF-2 $\alpha$ argue against their specific involvement since their effects are usually opposed or antagonistic (Kuehl, Cirillo, Ham \& Humen, 1973), the E series of prostaglandins being generally associated with vasodilatory activity (Dunham, Haddox \& Goldberg, 1974; Kadowitz, Joiner, Hyman \& George, 1975; Vane, 1976). The induction of implantational responses by both PGE-2 and PGF-2 $\alpha$ may, however, be related to the high doses used (Sananes et al., 1976; Hoffman et al., 1977). It has been shown (Hoffman et al., 1977) that PGE-2 is the more effective inducer of the decidual cell reaction, PGF- $2 \alpha$ requiring a release rate from an intrauterine Silastic implant 14 times that of PGE-2 to induce an equivalent response. In addition, Koch \& Oettel (1977) have demonstrated that PGF-2 $\alpha$ can inhibit trauma-induced deciduomata in rats subjected to various hormonal treatments.

Although the uterus is capable of producing prostaglandins in vivo (Kuehl, Cirillo, Zanetti, Beveridge \& Ham, 1976) synthesis and release of prostaglandins by the conceptus in vivo has not been demonstrated. Dickmann \& Spilman (1975) determined the presence of prostaglandins in rabbit preimplantation blastocysts but were sceptical about their direct involvement in the implantation process (Dickmann et al., 1976). Preliminary observations by Shemesh et al. (1979) indicated that the bovine blastocyst can be stimulated to synthesize prostaglandins ( $\mathrm{E}$ and F) in vitro under the influence of $\mathrm{LH}$.

Cyclic nucleotides are apparently under the control of prostaglandins (McMahon, 1974; Jimenez de Asua, Clingan \& Rudlands, 1975; Kuehl et al., 1976; Singhal, Tsang \& Sutherland, 1976) and are known to act as controlling factors in cellular differentiation and proliferation (Burger, Bombik, Breckenridge \& Sheppard, 1972; Otten, Johnson \& Pastan, 1972; McMahon, 1974; Simantov \& Sachs, 1975). It is not surprising, therefore, that their involvement in decidual cell formation has been considered. It is unlikely, however, that cyclic nucleotides provide the blastocyst-derived decidual stimulus since they are generally unable to cross cell membranes and are thought to act in a "second messenger" capacity (Sutherland, Butcher, Robison \& Hardman, 1967). 
Increased tissue levels of uterine cyclic AMP in the rat were found to coincide with the "oestradiol surge" after oestrus (Watson et al., 1975) and the onset of implantation. The increased rate of stromal mitosis which normally follows these events (Finn, 1977) occurred when cyclic AMP levels were falling or basal (Swift \& O'Grady, 1976). A similar relationship between cyclic AMP levels and cellular mitosis has been observed in other systems (Burger et al., 1972; Otten et al., 1972). A rapid but transient increase in cyclic AMP and cyclic GMP in uterine tissue following oil-induced decidualization indicated their involvement in the early events leading to decidual cell formation (Ledford, Rankin \& Baggett, 1975; Rankin, Ledford \& Baggett, 1977). In the rat, mouse and rabbit, however, neither intraperitoneal injection nor intraluminal application of cyclic AMP or dibutyryl cyclic AMP (dbcAMP) were effective in inducing deciduoma or the implantation of diapausal blastocysts (Leroy, Vansande, Shetgen \& Brasseur, 1974; Webb, 1975a; Holmes \& Bergstrom, 1976; Hoffman et al., 1977; Rankin et al., 1977; Wu \& Chang, 1977). Fisher \& Gunaga (1975) have reported that blastocyst development was retarded when cyclic AMP accumulation was induced following incubation with theophylline to inhibit the intracellular breakdown of cyclic AMP. Failure of the embryo to implant following cyclic AMP administration could thus be due to a direct influence on the embryo rather than a lack of effect on the endometrium.

It is generally accepted that cyclic nucleotides are not deciduogenic per se but there is conflicting evidence as to their role in implantation. Holmes \& Bergstrom (1975) and Webb (1975b) respectively have demonstrated that cyclic AMP and dbcAMP can precipitate implantation in mice maintained in experimental diapause. Ebert \& Fox (1977) have observed a similar effect using cyclic GMP in the rat. Webb (1977) has explained these findings by experiments using ovariectomized progesterone-treated mice in which intraluminal dbcAMP induced oestrogen-like changes in the luminal epithelium. Stromal mitosis was also observed, permitting subsequent oil induction of decidualization; this response is characteristic of oestrogen administration when the uterus is dominated by progesterone. In contrast to trauma-induced deciduoma, oil induction requires that the progestational uterus be primed with oestrogen, a situation corresponding to the normal physiological state (Finn \& Porter, 1975b). The implication is that dbcAMP can mimic oestradiol in inducing receptivity to implantation. This is supported by the findings of Holmes \& Bergstrom (1976) using similar conditions. They noted the ability of cyclic AMP to induce morphological changes in the diapausal blastocyst normally occurring after oestrogen activation before implantation. Since implantation did not follow, blastocyst activation may have arisen by the direct action of cyclic AMP or through a restricted oestrogen-mimicking action on the luminal epithelium, thereby removing the implantation inhibition characteristic of the epithelium during diapause. The actions of oestradiol and dbcAMP are also similar in their ability to induce synthesis of specific uterine luminal proteins (Surani \& Webb, 1977). In the experiments above in which cyclic nucleotides were administered to assess their influence on implantation, cellular uptake was assumed but not demonstrated.

Apparent changes in uterine levels of cyclic AMP in response to oestrogen administration have varied considerably in the hands of different investigators (Szego \& Davies, 1967; Rosenfeld \& O'Malley, 1970; Sanbourn, Bhalla \& Korenman, 1973; Zor, Koch, Lamprecht, Ausher \& Lindner, 1973; Koch, Zor, Lamprecht, Ausher \& Lindner, 1974; Flandroy \& Galand, 1975; Rinard \& Chew, 1975). It has been argued that such changes are not a direct consequence of oestrogen action, however, and evidence has been presented which indicates that several early uterine responses to oestradiol administration are independent of cyclic AMP mediation (Dupont-Mairesse, Van Sande, Rooryck, Fastrez-Boute \& Galand, 1974). A biphasic elevation of cyclic GMP rather than cyclic AMP has been observed by others (Kuehl et al., 1973, 1974; Flandroy, Fastrez-Boute \& Galand, 1976).

Elevated levels of cyclic AMP are generally associated with inhibition of cellular proliferation (Bombik \& Berger, 1973; Nose \& Katsuta, 1975) and decreasing levels with its induction (Burger et al., 1972), cyclic GMP having opposite effects (Goldberg \& Haddox, 1977). The 
influence of oestrogens on cyclic nucleotide levels has proved variable and it would seem essential to measure uterine levels of cyclic GMP and cyclic AMP simultaneously if their physiological role is to be determined. The data would be more conclusive if it were possible to measure cyclic nucleotide levels in different cell populations of the uterus. Although this is not feasible, measurement of adenylate cyclase activity in isolated cell types may provide a useful alternative.

\section{Embryonic hormones}

Although evidence of the ability of the preimplantation blastocyst to metabolize steroids in vitro has been available for some time (Huff \& Eik-Nes, 1966) only recently have functions been proposed (Dickmann \& Dey, 1973; Dickmann et al., 1976; Perry et al., 1973). It has been contended that initiation of implantation is regulated by steroids (particularly oestrogens) synthesized and secreted by the preimplantation conceptus. In the course of the oestrous cycle preovulatory ovarian oestradiol stimulates a similar but less localized endometrial stromal oedema to that produced at implantation (Finn \& Porter, 1975a). It is possible, therefore, that during the receptive phase when implantation is possible) secretion of oestradiol by the blastocyst could produce the localized and exaggerated uterine response associated with the initiation of implantation (Psychoyos, 1960).

Oestrogen secretion by the embryo has been suggested as a key factor in the initiation of implantation (see Dickmann et al., 1976). This theory is particularly attractive for those animals in which there is no apparent requirement for ovarian oestrogen at implantation since blastocyst oestrogen would presumably have the same effect. The rabbit has provided an interesting model with which to assess this contention because steroid hormones are present in the preimplantation blastocyst (Seamark \& Lutwak-Mann, 1972; Fuchs \& Beling 1974; Borland et al., 1977). Despite the capacity of the rabbit preimplantation embryo to synthesize steroids in vitro (Huff \& Eik-Nes, 1966; Singh \& Booth, 1978), the origin of these steroids is disputed and it has been suggested that it may be able to accumulate them from the uterine fluid (Smith, 1968; Seamark \& Lutwak-Mann, 1972; Bhatt \& Bullock, 1974; Holmes, 1976; Borland et al., 1977). Dickmann et al. (1977) have shown that localized release of oestradiol by rat preimplantation embryos can induce localized increases in vascular permeability when unsynchronized blastocysts, previously incubated with oestradiol, were transferred into the uteri of Day 5 pseudopregnant rats. Experiments involving the administration of the anti-oestrogen CI-628 to assess the involvement of embryonic oestrogens on implantation have, however, proved inconclusive since the subsequent failure of implantation was thought to be due primarily to its adverse effect on embryo development (Sen Gupta et al., 1977) rather than on the implantation process per se (Dey, Dickmann \& Sen Gupta, 1976).

In contrast to the ability of locally released oestradiol to induce the permeability reaction in rats (Dickmann et al., 1977) Hoffman et al. (1977) have observed the induction of a minimal decidual cell reaction in rabbits by intrauterine implants releasing between 8 and $90 \mu \mathrm{g}$ oestradiol over the implantation period. In the rat, $0.1 \mu \mathrm{g}$ oestradiol was sufficient to induce optimal conditions for implantation (Psychoyos, 1966) and such high release rates would certainly inhibit the decidual response (De Feo, 1967). Dickmann et al. (1977) consider it unlikely that incubation with oestradiol directly stimulated the release of a vasodilatory substance from the embryo, despite the presence of prostaglandins in the rabbit blastocyst (Dickmann \& Spillman, 1975), since these were probably derived from the uterine fluid. Nevertheless, Hoffman et al. (1977) have demonstrated the ability of intrauterine prostaglandin implants to induce a considerable decidual cell reaction in the rabbit.

Significant levels of oestrogens within the conceptus have not been demonstrated before or during the early attachment period in the cow and sheep (Table 1), and their ability to synthesize oestrogens from steroid precursors has not been established (Gadsby et al., 1976; Shemesh et 
al., 1979); androstenedione and progesterone were almost exclusively converted to neutral steroids (Gadsby et al., 1976). Significant progesterone synthesis was found in the bovine embryo in vitro, however, although this was not further stimulated by LH. Similarly, in the rat and mouse $\mathrm{LH}$ administration did not result in stimulation of steroid metabolism by cultured blastocysts (Dickmann, \& Dey, 1974b; Salomon \& Sherman, 1975).

Steroid metabolism in the post-implantation early conceptus is associated with binucleate trophoblast giant cells, particularly in rodent species (Deane, Rubin, Driks, Lobel \& Leipsner, 1962; Chew \& Sherman, 1975). The well developed endoplasmic reticulum and Golgi zone associated with the trophoblastic giant cells of farm animals may indicate a similar function in these species (Wislocki \& Bennett, 1943; Björkman, 1954; 1965; Davies \& Wimsatt, 1966). Trophoblast binucleate cells can be found from as early as Day 17 of gestation in the cow (Greenstein, Murray \& Foley, 1958) and Day 16 in the sheep (Boshier, 1969) and so in these species their appearance is linked with the early attachment period rather than the period of pregnancy recognition.

At the time of implantation the rabbit blastocyst has developed into an expanded bilaminar vesicle. This is similar to the sheep, cow and pig (although further development has occurred in these species by the time of attachment) but contrasts with rodents such as the rat, mouse and guinea-pig (Wimsatt, 1975). The ability to demonstrate blastocyst steroid metabolism in the rabbit (Huff \& Eik-Nes, 1966; George \& Wilson, 1978; Singh \& Booth, 1978) and the pig (Perry et al., 1973) but not the mouse (Antila et al., 1977; Sherman \& Atienza, 1977) may be associated with the presence of a greater diversity of cell types arising from the more advanced developmental stage.

The pig is the only domesticated animal in which the capacity of the pre-attachment conceptus to produce steroids has been extensively studied (Perry et al., 1973, 1976; Perry \& Heap, 1973; Robertson \& King, 1974; Heap et al., 1975; Gadsby et al., 1976; Robertson, King \& Carnegie, 1976; Van der Wiel \& Everts, 1977). Pregnancy recognition (Days 10-12, Dhindsa \& Dziuk, 1968) and initial attachment (Day 12, Crombie, 1970) occur at about the same time as the onset of embryonic steroid metabolism (Day 12, Perry et al., 1976), suggesting its involvement in these processes. Oestrone sulphate has been found in the allantoic fluid of the pig at Day 20 (Lunaas, Refsdel \& Schultz, 1973), and in pigs, sheep and cows at Days 27-40 (Eley, Thatcher \& Bazer, 1975; Robertson \& King, 1975; Robertson et al., 1976), corresponding more closely to the periods of areola or placentome formation than to the periods of initiation of attachment (Greenstein et al., 1958; Davies \& Wimsatt, 1966; Crombie, 1970; Atkinson, King, Carnegie \& Robertson, 1976). In the pig it seems likely that the oestrone sulphate is a product of the action of endometrial oestrogen sulphotransferase on oestrogen secreted by the conceptus rather than of sulphation by the embryo itself (Perry et al., 1973, 1976; Van der Wiel \& Everts, 1977). In fact, the porcine trophoblast possesses very high sulphatase activity at this time (Perry et $a l$., 1976). If the conceptuses of sheep and cows were similarly able to hydrolyse oestrone sulphate to oestrone, levels of allantoic oestrone sulphate at attachment would appear less important than the amounts of free oestrogens produced in this way.

The possible involvement of blastocyst oestrogen in decidual induction and implantation initiation was suggested by Shelesnyak (1960) and Shelesnyak \& Kraicer (1963), but it was not until 1972 that steroids (progesterone, 20 $\alpha$-hydroxypregn-4-en-3-one and 17 $\alpha$-hydroxyprogesterone) were first detected in preimplantation embryos (Seamark \& Lutwak-Mann, 1972). There is little doubt that the increased levels of uterine venous oestrone sulphate described from Days 14-16 of pregnancy in the pig conceptus (Robertson \& King, 1974; Van der Wiel \& Everts, 1977) are derived from oestrone synthesized by the conceptus, possibly from as early as Day 12 (Perry et al., 1976). Gadsby et al. (1976) have demonstrated that progesterone and/or pregnenolone may provide suitable substrates for its synthesis in vivo. However, the oestrogens and progestagens in the rabbit blastocyst before implantation may not arise as a consequence of steroid metabolism by the blastocyst. Singh \& Booth (1978) found no evidence of oestrogen 
synthesis in Day 6 rabbit blastocysts following incubation for $24 \mathrm{~h}$ with ${ }^{3} \mathrm{H}$-labelled progesterone or androgens. George \& Wilson (1978) have noted the formation of androstenedione and testosterone from ${ }^{3} \mathrm{H}$-labelled dehydroepiandrosterone and oestradiol from tritiated testosterone. Although androgen synthesis was detected in vitro before implantation, it was not possible to determine whether oestradiol synthesis could occur at the time of implantation (Day 6.5): oestradiol was present on Day 7 but not at Day 6. If the appropriate enzyme activity was present in vitro at the time of implantation, it still could not be assumed that the steroid content of the blastocyst derived largely from this source. Seamark \& Lutwak-Mann (1972) detected the same steroids in the blastocyst and uterine fluids of pregnant and pseudopregnant rabbits (at Days 5 and 6), suggesting that the progestagens measured may have been derived from the uterine fluid. On Day 5, however, the levels of progesterone and $20 \alpha$-dihydroprogesterone in the blastocyst were higher than those in maternal plasma Seamark \& Lutwak-Mann, 1972; Fuchs \& Beling, 1974). Borland et al. (1977) consider it signficant that the uterine fluid accumulates considerable levels of progesterone and to a lesser extent oestrogen at this time, presumably from the ovary (either via the oviduct or from the plasma). They infer that blastocyst levels are determined, through selective absorption, by the steroid content of the uterine fluid. This is supported by the work of Fujimoto \& Sundaram (1978) who measured progesterone levels in rabbit blastocysts at Days 6 and 7, and in maternal serum and uterine fluid. By comparing levels in intact animals with those in ovariectomized medroxyprogesterone acetate-maintained animals it was apparent that most of the progesterone found in the normal blastocysts was derived from the maternal ovaries. The small amount of progesterone detected in the blastocysts of ovariectomized animals was attributed to de novo synthesis by the blastocyst or to maternal adrenal activity. Similarly, the fate of $\left[{ }^{3} \mathrm{H}\right]$ oestradiol when injected into pregnant rabbits led Singh \& Booth (1978) to conclude that blastocyst oestrogen may be partly of maternal origin.

The presence of ovarian steroids in uterine luminal fluid as opposed to other mucosal secretions (Eiler, Bahr \& Nalbandov, 1977) may be due to the presence of specific binding proteins (Beato \& Baier, 1975; Fowler, Johnson, Walters \& Pratt, 1976; Fowler, Johnson, Walters \& Eager, 1977). Eiler et al. (1977) have distinguished changes in rabbit luminal fluid steroids which can be initiated by the mating stimulus or $\mathrm{LH}$ injection but which did not necessarily parallel plasma steroid levels. Maximal levels of both oestrogen and progesterone were attained at about the time of implantation. Fowler et al. $(1976,1977)$ have noted similar increases in uterine fluid progesterone during pregnancy and pseudopregnancy in the rabbit but failed to detect oestrogen during the same period (in contrast to Borland et al., 1977, and Eiler et al., 1977). Changes in luminal fiuid progesterone always followed similar changes in the protein content of luminal fluid (Fowler et al., 1977): despite high plasma levels, progesterone did not appear in the uterine fluid unless uterine protein was present.

In the light of current knowledge, if the blastocyst is indeed a target tissue for luminal fluid steroids or acts as a carrier before implantation (Shelesnyak, 1960) then the presence of specific binding proteins or receptors within the blastocyst would be expected (Gorski, Toft, Shyamala, Smith \& Notides, 1968; Jensen et al., 1968). Smith (1968) noted an increased frequency of implantation with embryos treated in vitro with oestradiol before transfer to ovariectomized progesterone-treated mice, but it was not possible to determine whether this was due to a direct influence by oestradiol on the uterus or to its influence on the embryo itself. The oestradiol was apparently retained by the embryo, although this has been questioned (Wu \& Meyer, 1970). The technique used by Smith (1968) has been further developed and has provided similar results in the rat (Dickmann et al., 1976, 1977). There is evidence for the presence of soluble proteins capable of specifically binding oestradiol in the rabbit blastocyst (Bullock \& Bhatt, 1973; Bhatt \& Bullock, 1974). This binding may be inhibited by CI-628 with an associated reduction in implantation rate. Similar investigations by Sen Gupta et al. (1977) indicate that CI-628 may exhibit its anti-oestrogen effect by interfering with blastocyst development rather than by acting directly on the implantation process. Such binding proteins have been characterized by Holmes 
(1976) in the rabbit and mouse and the specificity of their binding sites and sedimentation coefficients (8S) shown to be comparable with those of other target tissues.

In many species embryonic loss in the pre- and peri-attachment periods is inherently high and this enigma has withstood resolution for many years. Hormonal aspects of this phenomenon have only been approached superficially and recent observations of hormonal interactions between blastocyst and uterus in laboratory species may throw light on the causes. The period when histotrophe secretion becomes restricted at the time of conceptus attachment may be particularly critical in farm animals and steroid exchanges between conceptus and endometrium could well play a role in controlling the transition from histotrophic to placental nutrition. Demonstration of steroid receptors within the chorionic vesicle would indicate whether the embryo can be influenced by steroid hormones and definition of the origin and nature of the steroids present in the uterine fluid would suggest those potentially available to the embryo. In cattle and sheep there is a particular need to define endometrial changes in terms of the predetermined attachment sites (caruncles) and inter-caruncular regions. The difficulties encountered in separating uterine cell types in laboratory species should be more readily overcome in the larger farm animals and allow more exact hormonal studies.

I thank Dr J. A. Foulkes for his continuing interest and constructive suggestions during this study and Dr G. S. Pope, of the National Institute for Research in Dairying, and Mr R. W. Saunders for their helpful criticisms. I am particularly grateful to Mrs L. Temporal for her patient dedication while typing the manuscript.

\section{References}

Aitken, R.J. (1977) Changes in the protein content of mouse uterine flushings during normal pregnancy and delayed implantation, and after ovariectomy and oestradiol administration. J. Reprod. Fert. 50, 2936.

Andary, T.J., Dabich, D. \& Van Winkle, L.J. (1972) Changes in proteinase activity in early vs. late mouse blastocysts. J. Cell Biol. 55, 3a, Abstr.

Anon (1975) Gonadotrophin in cleaving mouse embryos. Res. Reprod. 7, 4.

Antila, E., Koskinen, J., Niemala, P. \& Saure, A. (1977) Steroid metabolism by mouse preimplantation embryos in vitro. Experientia 33, 1374-1375.

Atkinson, B., King, G.J., Carnegie, J.A. \& Robertson, H.A. (1976) Relationship between bovine implantation and estrogens produced by the conceptus. Proc. 8th Int. Congr. Anim. Reprod. \& A.I., Krakow, 3, 279-282.

Bassett, J.M., Oxborrow, T.J., Smith, I.D. \& Thorburn, G.D. (1969) Concentration of progesterone in the peripheral plasma of the pregnant ewe. J. Endocr. 45, 449-457.

Baulieu, E.-E., Atger, M., Best-Belpomme, M., Corvol, P., Courvalin, J.-C., Mester, J., Milogram, E., Robel, P., Rochefort, H. \& de Catalogne, D. (1975) Steroid hormone receptors. Vitams Horm. 33, 649-736.

Bazer, F.W. \& Thatcher, W.W. (1977) Theory of maternal recognition of pregnancy in swine based on estrogen controlled endocrine versus exocrine secretion of prostaglandin-F2 alpha by the uterine endometrium. Prostaglandins 14, 397-401.

Beato, M. \& Baier, R. (1975) Binding of progesterone to the proteins of the uterine luminal fluid: identifcation of uteroglobin as the binding protein. Biochim. Biophys. Acta 392, 346-356.
Betteridge, K.J., Mitchell, D., Eaglesome, M.D. \& Randall, G.C.B. (1976) Embryo transfer in cattle 10-17 days after estrus. Proc. 8th Int. Congr. Anim. Reprod. \& A.I., Krakow, 3, 237-240.

Bhatt, B.M. \& Bullock, D.W. (1974) Binding of oestradiol to rabbit blastocysts and its possible role in implantation. J. Reprod. Fert. 39, 65-70.

Biggers, J.D. (1971) Metabolism of mouse embryos. $J$. Reprod. Fert., Suppl. 14, 41-54.

Bindon, B.M. (1971) Role of progesterone in implantation in the sheep. J. Reprod. Fert. 24, 146.

Björkman, N. (1954) Morphological and histochemical studies in the bovine placenta. Acta anat., Suppl. 22.

Björkman, N. (1965) Fine structure of the ovine placentome. J. Anat. 99, 283-297.

Björkman, N. (1970) The epitheliochorial placenta. In An Atlas of Placental Fine Structure, p. 16. Baillière \& Tindall, London.

Bombik, B.M. \& Burger, M.M. (1973) c-AMP and the cell cycle: inhibition of growth stimulation. Expl. Cell Res. 80, 88-94.

Borland, R.M., Erickson, G.F. \& Ducibella, T. (1977) Accumulation of steroids in rabbit preimplantation blastocysts. J. Reprod. Fert. 49, 219-224.

Boshier, D.P. (1969) A histological and histochemical examination of implantation and early placentome formation in sheep. J. Reprod. Fert. 19, 51-61.

Boshier, D.P. (1970) The Pontamine Blue reaction in pregnant sheep uteri. J. Reprod. Fert. 22, 595-596.

Brandon, J.M. \& Wallis, R.M. (1977) Effect of mepyramine, a histamine $\mathrm{H}_{1}{ }^{-}$, and burimamide, a histamine $\mathrm{H}_{2}$-receptor antagonist, on ovum implantation in the rat. J. Reprod. Fert. 50, 251-254.

Buchanan, G.D., Enders, A.C. \& Talmage, R.V. (1956) Implantation in armadillos ovariectomized during 
the period of delayed implantation. J. Endocr. 14, 121-128.

Bullock, D.W. \& Bhatt, B.M. (1973) Oestrogen binding to rabbit blastocysts and its possible role in implantation. J. Reprod. Fert. 35, 614.

Burger, M.M., Bombik, B.M., Breckenridge, B.McL. \& Sheppard, J.R. (1972) Growth control and cyclic alterations of cyclic AMP in the cell cycle. Nature, New Biol 239, 161-163.

Castracane, V.D., Saksena, S.K. \& Shaikh, A.A. (1974) Effect of IUD's prostaglandins and indomethacin on decidual cell reaction in the rat. Prostaglandins 6, 397-404.

Castracane, V.D. \& Shaikh, A.A. (1976) Effect of decidual tissue on the uterine production of prostaglandins in pseudopregnant rats. J. Reprod. Fert. 46, 101-104.

Cerini, M., Cerini, J.C., Findlay, J.K. \& Lawson, R.A.S. (1976) An immunological test for pregnancy in domestic animals. Proc. 8th Int. Congr. Anim. Reprod.\& A.I., Krakow, 3, 342-345.

Cerini, M., Findlay, J.K. \& Lawson, R.A.S. (1976) Pregnancy-specific antigens in the sheep: application to the diagnosis of pregnancy. J. Reprod. Fert. 46, 65-69.

Chang, M.C. (1950) Development and fate of transferred rabbit ova or blastocysts in relation to the ovulation time of the recipients. J. exp. Zool. 114, 197-225.

Chatterton, R.T., Jr, MacDonald, G.J. \& Ward, D.A. (1975) Effect of blastocysts on rat ovarian steroidogenesis in early pregnancy. Biol. Reprod. 13, $77-82$.

Chew, N.J. \& Sherman, M.I. (1975) Biochemistry of differentiation of mouse trophoblast: $\Delta 5,3 \beta$ hydroxysteroid dehydrogenase. Biol. Reprod. 12, 351-359.

Cowell, T.P. (1969) Implantation and development of mouse eggs transferred to the uteri of nonprogestational mice. J. Repod. Fert. 19, 239-245.

Crombie, P.R. (1970) Ultrastructure of the foetalmaternal attachment in the pig. J. Physiol., Lond. 210, $101 P-102 P$.

Cumming, I.A., Baxter, R. \& Lawson, R.A.S. (1974) Steroid hormone requirements for the maintenance of early pregnancy in sheep. A study using ovariectomized adrenalectomized ewes. J. Reprod. Fert. $\mathbf{4 0}$, $443-446$.

Davies, I.J. \& Ryan, K.J. (1972) Comparative endocrinology of gestation. Vitams Horm. 30, 223-279.

Davies, J. \& Wimsatt, W.A. (1966) Observation on the fine structure of the sheep placenta. Acta anat. 65, 182-223.

Deane, H.W., Rubin, B.L., Driks, E.C., Lobel, B.L. \& Leipsner, G. (1962) Trophoblastic giant cells in placentas of rats and mice and their probable role in steroid-hormone production. Endocrinology 70 , 407-419.

Deanesly, R. (1960) Implantation and early pregnancy in ovariectomized guinea-pigs. J. Reprod. Fert. 1, 242-248.

De Feo, V.J. (1967) Decidualization. In Cellular Biology of the Uterus, pp. 191-290. Ed. R. M. Wynn. North Holland Pub. Co., Amsterdam.

Denker, H.W. (1972) Blastocyst protease and implantation: effect of ovariectomy and progesterone sub- stitution in the rabbit. Acta endocr., Copenh. $\mathbf{7 0}$ 591-602.

Denker, H.W. (1976) Formation of the blastocyst: determination of trophoblast and embryonic knob. Curr. Top. Path. 62, 59-79.

Dey, S.K. \& Dickmann, Z. (1974a) Estradiol-17ßhydroxysteroid dehydrogenase activity in preimplantation rat embryos. Steroids 24, 57-62.

Dey, S.K. \& Dickmann, Z. (1974b) $\Delta^{5}-3 \beta$-hydroxysteroid dehydrogenase activity in rat embryos on days 1 through 7 of pregnancy. Endocrinology 95, $321-322$.

Dey, S.K. \& Dickmann, Z. (1974c) $\Delta^{5}-3 \beta-$ hydroxysteroid dehydrogenase in mouse morulae and blastocysts. Proc. 7th A. Mtg, Soc. Study Reprod. Abstr. No. 150.

Dey, S.K., Dickmann, Z. \& Sen Gupta, J. (1976) Evidence that the maintenance of early pregnancy in the rabbit requires "blastocyst estrogen". Steroids 28, 481-485.

Dhindsa, D.S. \& Dziuk, P.J. (1968) Effect of pregnancy in the pig after killing embryos or fetuses in one uterine horn in early gestation. J. Anim. Sci. 27, $122-126$.

Dickmann, Z. (1969) Shedding of the zona pellucida. Adv. Reprod. Physiol. 4, 187-206.

Dickmann, Z. (1972) Effects of progesterone, medroxyprogesterone acetate (Provera) and oestrone on shedding and dissolution of the zona pellucida in the rat. J. Endocr. 54, 39-45.

Dickmann, Z. \& Dey, S.K. (1973) Two theories: the preimplantation embryo is a source of steroid hormones controlling (i) morula-blastocyst transformation, and (ii) implantation. J. Reprod. Fert. 35, 615-617.

Dickmann, Z. \& Dey, S.K. (1974a) $\Delta^{5}-3 \beta$-hydroxysteroid dehydrogenase activity in rat blastocysts under various experimental conditions. Anat. Rec. 178, 345, Abstr.

Dickmann, Z. \& Dey, S.K. (1974b) Evidence that $\Delta 5$ $3 \beta$-hydroxysteroid dehydrogenase activity in rat blastocysts is autonomous. J. Endocr. 61, 513-514.

Dickmann, Z. \& Day, S.K. (1974c) Steroidogenesis in the preimplantation rat embryo and its possible influence on morula-blastocyst transformation and implantation. J. Reprod. Fert. 37, 91-93.

Dickmann, Z. \& Sen Gupta, J. (1974) $\Delta^{5}-3 \beta$-hydroxysteroid dehydrogenase and estradiol-17 $\beta$-hydroxysteroid dehydrogenase activity in preimplantation hamster embryos. Devl Biol. 40, 196-198.

Dickmann, Z. \& Spillman, C.H. (1975) Prostaglandins in rabbit blastocysts. Science, N.Y. 190, 997-998.

Dickmann, Z., Dey, S.K. \& Sen Gupta, J. (1975a) Evidence of steroidogenesis in rabbit preimplantation embryos. Anat. Rec. 181, 346-347.

Dickmann, Z., Dey, S.K. \& Sen Gupta, J. (1975b) Steroidogenesis in rabbit preimplantation embryos. Proc. natn. Acad. Sci. U.S.A. 72, 298-300.

Dickmann, Z., Dey, S.K. \& Sen Gupta, J. (1976) A new concept: control of early pregnancy by steroid hormones originating in the preimplantation embryo. Vitams Horm. 34, 215-242.

Dickmann, Z. Sen Gupta, J. \& Dey, S.K. (1977) Does "blastocyst estrogen" initiate implantation? Science, N.Y. 195, 687-688. 
Dunham, E.W., Haddox, M.K. \& Goldberg, N.D. (1974) Alteration of vein cyclic $3^{\prime}: 5^{\prime}$ nucleotide concentrations during changes in contractility. Proc. natn. Acad. Sci. U.S.A. 71, 815-819.

Dupont-Mairesse, N., Van Sande, J., Rooryck, J., Fastrez-Boute, A. \& Galand, P. (1974). Mechanisms of estrogen action-independence of several responses of the rat uterus from the early increase in adenosine 3',5'-cyclic monophosphate. J. Steroid Biochem. 5, 173-178.

Ebert, K.M. \& Fox, K.A. (1977) Induction of implantation in the rat by cyclic nucleotides. Contraception 16, 149-154.

Eiler, H., Bahr, J. \& Nalbandov, A.V. (1977) Ovarian steroids in the uterine lumena. 1. Effect of LH injection and mating in rabbits. Biol. Reprod. 17, $459-464$.

Eley, R.M., Thatcher, W.W. \& Bazer, F.W. (1975) Hormone changes associated with bovine conceptus development. J. Anim. Sci. 41, 350-351, Abstr.

Ellinwood, W.E., Siedel, S.M. \& Niswender, G.D. (1977) Preimplantation gonadotrophin in the rabbit. Proc. IOth A. Mtg, Soc. Study Reprod., Abstr. No. 120.

Enders, A.C. (1976) Anatomical aspects of implantation. J. Reprod. Fert., Suppl. 25, 1-15.

Enders, A.C. \& Given, R.L. (1977) The endometrium of delayed and early implantation. In The Biology of the Uterus, 2nd edn. pp. 203-243. Ed. R. M. Wyan. Plenum, New York.

Fawcett, D.W., Wislocki, G.B. \& Waldo, C.M. (1947) The development of mouse ova in the anterior chamber of the eye and in the abdominal cavity. $A \mathrm{~m}$. J. Anat. 81, 413-443.

Finn, C.A. (1977) The implantation reaction. In The Biology of the Uterus, 2nd edn. pp. 245-308. Ed. R. M. Wynn. Plenum, New York.

Finn, C.A. \& Martin, L. (1970) The role of the oestrogen secreted before oestrus in the preparation of the uterus for implantation in the mouse. J. Endocr. 47, $431-438$.

Finn, C.A. \& Martin, L. (1974) The control of implantation. J. Reprod. Fert. 39, 195-206.

Finn, C.A. \& McLaren, A. (1967) A study of the early stages of implantation in mice. J. Reprod. Fert. 13, 259-267.

Finn, C.A. \& Porter, D.G. (1975a) The action of ovarian hormones on the endometrium. In The Uterus, pp. 42-56. Eds C. A. Finn \& D. G. Porter. Paul Elek (Scientific Books) Ltd., London.

Finn, C.A. \& Porter D.G. (1975b) Decidual cell reaction. In The Uterus, pp. 74-85. Eds C. A. Finn \& D. G. Porter. Paul Elek (Scientific Books) Ltd, London.

Finn, C.A. \& Porter, D.G. (1975c) The control of implantation and the decidual cell reaction. In The Uterus, pp. 86-95. Eds C. A. Finn \& D. G. Porter. Paul Elek (Scientific Books) Ltd, London.

Fisher, D.L. \& Gunaga, K.P. (1975) Theophylline induced variations in cyclic AMP content of the superovulated preimplantation mouse embryo. Biol. Reprod. 12, 471-476.

Flandroy, L., Fastrez-Boute, A. \& Galand, P. (1976) Oestrogen-induced changes in uterine cGMP: relationship with other parameters of hormonal stimulation. Archs int. Physiol. Biochim. 84, 10721073.
Flandroy, L. \& Galand, P. (1975) Oestrogen-related changes in uterine and vaginal cAMP and cGMP. Archs int. Physiol. Biochim. 83, 965-967.

Flint, A.P.F. \& Hillier, K. (1975) Prostaglandins and reproductive processes in female sheep and goats. In Prostaglandins and Reproduction, pp. 271-308. Ed. S. M. Karim. University Park Press, Baltimore.

Flood, P.F. (1974) Steroid-metabolizing enzymes in the early pig conceptus and in related endometrium. $J$. Endocr. 63, 413-414.

Flood, P.F. \& Marrable, A.W. (1975) A histochemical study of steroid metabolism in the equine fetus and placenta. J. Reprod. Fert., Suppl. 23, 569-573.

Flower, R.J. (1974) Drugs which inhibit prostaglandin biosynthesis. Pharmcol. Rev. 26, 33-67.

Foote, W.D., Gooch, L.D., Pope, A.L. \& Casida, L.E. (1957) The maintenance of early pregnancy in the ovariectomized ewe by injection of ovarian hormones. J. Anim. Sci. 16, 986-989.

Fowler, R.E., Johnson, M.H., Walters, D.E. \& Pratt, H.P.M. (1976) The progesterone and protein composition of rabbit uterine flushings. J. Reprod. Fert. 46, 427-430.

Fowler, R.E., Johnson, M.H., Walters, D.E. \& Eager, D.D. (1977) Progesterone content of rabbit uterine flushings. J. Reprod. Fert. 50, 301-308.

Fuchs, A.R. \& Beling, C. (1974) Evidence for early ovarian recognition of blastocyst in rabbits. Endocrinology 95, 1054-1058.

Fuchs, F. \& Klopper, A. (1977) Endocrinology of Pregnancy. Harper \& Row, Maryland.

Fujimoto, S. \& Sundaram, K. (1978) The source of progesterone in rabbit blastocysts. $J$. Reprod. Fert. 52, 231-233.

Fujimoto, S. \& Tanaka, T. (1975) Gonadotrophin activities in the prenidation blastosphere fluid. Clin. Endocr., Tokyo 23, 707-709.

Fujimoto, S., Enker, J.S., Riegle, G.D. \& Dukelow, W.R. (1975) Substances cross reacting with $\mathrm{LH}$ in the preimplantation blastocyst fluid of the rabbit. Proc. Jap. Acad. 51, 123-125.

Gadsby, J.E., Burton, R.D., Heap, R.B. \& Perry, J.S. (1976) Steroid metabolism and synthesis in early embryonic tissue of pig, sheep and cow. $J$. Endocr. 71, 45P-46P, Abstr.

Gardner, M.L., First, N.L. \& Casida, L.E. (1963) Effect of exogenous estrogens on corpus luteum maintenance in gilts. J. Anim. Sci. 22, 132-134.

Gentry, B.E., Anderson, L.L. \& Melampy, R.M. (1973) Exogenous progesterone and estradiol benzoate on early embryonic survival in the pig. J. Anim. Sci. 37, $722-727$.

George, F.W. \& Wilson, J.D. (1978) Estrogen formation in the early rabbit embryo. Science, N.Y. 199, 200-201.

Glasser, S.R. \& Clark, J.M. (1975) Determinant role for progesterone in the development of uterine sensitivity to decidualization and ova implantation. In The Developmental Biology of Reproduction, pp. 331-345. Eds C. L. Markert \& J. Popaconstantinou. Academic Press, New York.

Goldberg, N.D. \& Haddox, M.K. (1977) Cyclic GMP metabolism and its involvement in biological regulation. A. Rev. Biochem. 46, 823-896.

Goldenberg, R.L., Bridson, W.E. \& Kohler, P.O. (1972) Estrogen stimulation of progesterone synthesis by 
porcine granulosa cells in culture. Biochem. Biophys. Res. Commun. 48, 101-107.

Gorski, J., Toft, D., Shyamala, G., Smith, D. \& Notides, A. (1968) Hormone receptors: studies on the interaction of estrogen with the uterus. Recent Prog. Horm. Res. 24, 45-80.

Greenstein, J.S., Murray, R.W. \& Foley, R.C. (1958) Observation on the morphogenesis and histochemistry of the bovine pre-attachment placenta between 16 and 33 days of gestation. Anat. Rec. 132, $321-341$.

Haour, F. \& Saxena, B.B. (1974) Detection of gonadotrophin in rabbit blastocyst before implantation. Science, N.Y. 185, 444-445.

Harrer, J.A. \& Lee, L.H. (1973) Differential effects of oestrogen on the uptake of nucleic acid precursors by mouse blastocysts in vitro. J. Reprod. Fert. 33, 327-330.

Hawk, H.W., Brinsfield, T.H., Turner, G.D., Whitmore, G.E. \& Norcross, M.A. (1963) Embryo survival in first-service and repeat-breeder cattle after ovariectomy and hormone therapy. J. Dairy Sci. 46, 13971401.

Heald, P.J. (1976) Biochemical aspects of implantation. J. Reprod. Fert., Suppl. 25, 29-52.

Heap, R.8. \& Perry, J.S. (1974) Maternal recognition of pregnancy. Br.J. Hosp. Med. 12, 8-14.

Heap, R.B., Perry, J.S., Gadsby, J.E. \& Burton, R.D. (1975) Endocrine activities of the blastocyst and early embryonic tissue in the pig. Biochem. Soc. Trans. 3, 1183-1 188.

Henderson, K.M. \& McNatty, K.P. (1975) A biochemical hypothesis to explain the mechanism of luteal regression. Prostaglandins 9, 779-797.

Henderson, K.M., Scaramuzzi, R.J. \& Baird, D.T. (1977) Simultaneous infusion of prostaglandin E-2 antagonizes the luteolytic action of prostaglandin F$2 \alpha$ in vivo. J. Endocr. 72, 379-383.

Hoffman, L.H. (1977) Effect of indomethacin on blastocyst development and implantation in the rabbit. Anat. Rec. 187, 606, Abstr.

Hoffman, L.H., Strong, G.B., Davenport, G.R. \& Fröhlich, J.C. (1977) Deciduogenic effect of prostaglandins in the pseudopregnant rabbit. J. Reprod. Fert. 50, 231-237.

Hogden, G.D., Wolfe, L.G., Ogden, J.D., Adams, M.R., Descalzi, C. \& Hildebrand, D.F. (1976) Diagnosis of pregnancy in the marmoset: haemagglutination inhibition tests and radio immunoassay for urinary chorionic gonadotrophin. Lab. Anim. Sci. 26, 224229.

Holmes, P.V. (1976) Evidence of cytosol receptor protein specific for estradiol in the preimplantation blastocyst. Proc. 8th Int. Congr. Anim. Reprod. \& A.I., Krakow, vol. 3, 290-293.

Holmes, P.V. \& Bergstrom, S. (1975) Induction of blastocyst implantation in mice by cyclic AMP. $J$. Reprod. Fert. 43, 329-332.

Holmes, P.V. \& Bergstrom, S. (1976) Cyclic adenosine monophosphate-induced changes in surface morphology of diapausing blastocysts and effects on implantation. Am. J. Obstet. Gynec. 124, 301-306.

Holt, J.A., Heise, W.F., Wilson, S.M. \& Keyes, P.L. (1976) Lack of gonadotrophic activity in the rabbit blastocyst prior to implantation. Endocrinology 98 , 904-909.
Huff, R.L. \& Eik-Nes, K.B. (1966) Metabolism in vitro of acetate and certain steroids by six-day-old rabbit blastocysts. J. Reprod. Fert. 11, 57-63.

Jensen, E.V., Suzuki, T., Kawashima, T., Stumpf, W., Jungblut, P.W. \& De Sombre, E.R. (1968) A twostep mechanism for the interaction of estradiol with the rat uterus. Proc. natn. Acad. Sci. U.S.A. 59, 632-638.

Jimenez de Asua, L., Clingan, D. \& Rudlands, P.S. (1975) Initiation of cell proliferation in cultured mouse fibroblasts by prostaglandin F-2 $\alpha$. Proc. natn. Acad. Sci. U.S.A. 72, 2724-2728.

Joshi, M.S. \& Murray, I.M. (1974) Immunological study of rat uterine fluid peptidase. J. Reprod. Fert. 37, 361-365.

Kadowitz, P.J., Joiner, P.D., Hyman, A.L. \& George, W.J. (1975) Influence of prostaglandins $E_{1}$ and $F_{2}$ on pulmonary vascular resistance, isolated lobar vessels and cyclic nucleotide levels. J. Pharmac. exp. Ther. 192, 677-687.

Kennedy, T.G. (1976) Are prostaglandins involved in implantation in rats? Proc. 5th Int. Congr. Endocr., Hamburg, Abstr. No. 83.

Kennedy, T.G. (1977) Evidence for a role for prostaglandins in the initiation of blastocyst implantation in the rat. Biol. Reprod. 16, 286-291.

King, R.J.B. \& Mainwaring, W.I.P. (1973) Steroid-Cell Interactions. Butterworths, London.

King, R.J.B. \& Thompson, J. (1974) Effects of oestradiol in different cell types. Adv. exp. Med. Biol. 44, 367381 .

Kirby, D.R.S. (1963a) The development of mouse blastocysts transplanted to the scrotal and cryptorchid testis. J. Anat. 97, 119-130.

Kirby, D.R.S. (1963b) Development of the mouse blastocyst transplanted to the spleen. J. Repod. Fert. 5, $1-12$

Klopper, A. \& Diczfalusy, F. (1969) Foetus and Placenta. Blackwell, Oxford.

Koch, M. \& Oettel, M. (1977) Inhibition of the deciduoma cell response in pseudopregnant rats after prostaglandin F2 $\alpha$ treatment. Endokrinologie 69, 355-358.

Koch, Y., Zor, U., Lamprecht, S.A., Ausher, J. \& Lindner, H.R. (1974) Mechanism of oestradiol action on the rat uterus. Independance of cyclic AMP, prostaglandin $E_{2}$ and $\beta$-adrenergic mediation. Israel J. med. Sci. 10, 573.

Kosasa, T., Levesque, L., Goldstein, D.P. \& Taymor, M.L. (1973) Early detection of implantation using a radioimmunoassay specific for HCG. J. clin. Endocr. Metab. 36, 622-624.

Kuehl, F.A., Jr, Cirillo, V.J., Ham, E.A. \& Humen, J.F. (1973) The regulatory role of the prostaglandins on the cyclic $3^{\prime} 5^{\prime}$ AMP system. Adv. Biosci. 9, 155172.

Kuehl, F.A., Jr, Ham, E.A. Zanetti, M.E., Sanford, C.H., Nicol, S.E. \& Goldberg, N.D. (1974) Estrogenrelated increases in uterine guanosine $3^{\prime}: 5^{\prime}$ cyclic monosphosphate levels. Proc. natn. Acad. Sci. U.S.A. 71, 1866-1870.

Kuehl, F.A., Cirillo, V.J., Zanetti, M.E., Beveridge, G.C. \& Ham, E.A. (1976) Effect of estrogen on cyclic nucleotide and prostaglandin levels in rat uterus. Adv. Prostaglandin and Thromboxane Res. 1, 313324. 
Laster, D.B. (1977) Pregnancy-specific protein in the bovine uterus. Biol. Reprod. 16, 682-690.

Ledford, B.B., Rankin, J.C. \& Baggett, B. (1975) Cyclic nucleotide levels in the mouse uterus during artifically stimulated decidualization. Fedn. Proc. Fedn Am. Socs exp. Biol. Abstr. 2702.

Leiser, R. (1975) Development of contact between trophoblast and uterine epithelium during the early stages of implantation in the cow. Anatomia Histologia Embryologia 4, 63-86.

Leroy, F., Vansande, J., Shetgen, G. \& Brasseur, D. (1974) Cyclic AMP and the triggering of the decidual reaction. J. Reprod. Fert. 39, 207-211.

Levy, H., Deane, H.W. \& Rubin, B.L. (1959) Visualization of steroid-3 $\beta$-ol-dehydrogenase activity in tissues of intact and hypophysectomised rats. Endocrinology 65, 932-943.

Lunaas, T., Refsdel, A.O. \& Schultz, R.H. (1973) Conjugated oestrone in uterine vein blood during early pregnancy in the pig. Acta endocr., Copenh., Suppl. 177, 42, Abstr.

Mapletoft, R.J., Del Campo, M.R. \& Ginther, O.J. (1975) Unilateral luteotrophic effect of uterine venous effluent of a gravid uterine horn in sheep. Proc. Soc. exp. Biol. Med. 150, 129-133.

Mapletoft, R.J., Lapin, D.R. \& Ginther, O.J. (1976) The ovarian artery as the final component of the local luteotrophic pathway between a gravid uterine horn and ovary in ewes. Biol. Reprod. 15, 414-421.

Marcus, G.J. \& Shelesnyak, M.C. (1970) Steroids in nidation. Adv. Steroid Biochem. Pharmac. 1, 373438.

Martal, J. \& Djiane, J. (1977) The production of chorionic somatomammotrophin in sheep. $J$. Reprod. Fert. 49, 285-289.

Martal, J., Lacroix, M.-C., Loudes, C., Saunier, M. \& Wintenberger-Torrès, S. (1979) Trophoblastin, an antiluteolytic protein present in early pregnancy in sheep, J. Reprod. Fert. 56, 63-73.

McLaren, A. (1970) The fate of the zona pellucida in mice. J. Embryol. exp. Morph. 23, 1-19.

McLaren, A. (1973) Blastocyst activation. In Regulation of Mammalian Reproduction, pp. 321-328. Eds S. J. Segal, R. Crozier, P. A. Corfman \& P. G. Condliffe. C. C. Thomas, Springfield.

McLaren, A. (1974) Fertilization, cleavage and implantation. In Reproduction in Farm Animals, 3rd edn, pp. 143-165. Ed. E. S. E. Hafez. Lea \& Febigo, Philadelphia.

McMahon, D. (1974) Chemical messengers in development: a hypothesis. Science, N.Y. 185, 1012-1021.

Meyer, R.K., Wolf, R.C. \& Arslan, M. (1969) Implan tation and maintenance of pregnancy in progesterone-treated ovariectomized monkeys (Macaca mulatta). Proc. 2nd Int. Congr. Primat. 2, 30-35.

Mintz, B. (1971) Control of embryo implantation and survival. Adv. Biosci. 6, 317-342.

Mintz, B. (1972) Implantation initiating factor from mouse uterus. In Biology of Mammalian Fertilization and Implantation, pp. 343-356, Eds K. M. Moghissi \& E. S. E. Hafez. C. C. Thomas, Springfield.

Moor, R.M. (1968) Effect of embryo on corpus luteum function. J. Anim. Sci. 27, Suppl. 1, 97-118.
Moor, R.M. \& Rowson, L.E.A. (1959) Maintenance of pregnancy in ovariectomised ewes by means of progesterone. Nature, Lond. 184, 1410.

Moor, R.M. \& Rowson, L.E.A. (1966) Local maintenance of the corpus luteum in sheep with embryos transferred to various isolated portions of the uterus. J. Reprod. Fert. 12, 539-550.

Morton, H., Nancarrow, C.D., Scaramuzzi, R.J., Evison, B.M. \& Clunie, G.T.A. (1979) Detection of early pregnancy in sheep by the rosette inhibition test. $J$. Reprod. Fert. 56, 75-80.

Nalbandov, A.V. (1976) Pregnancy, parturition and lactation. In Reproductive Physiology of Mammals and Birds, 3rd edn, pp. 276-303. Ed. A. V. Nalbandov, W. H. Freeman \& Co, San Francisco.

Nilson, O. (1970) Some ultrastructural aspects of ovoimplantation. In Ovoimplantation, Human gonadotrophins and Prolactin, pp. 52-72. Eds P. O. Hubinot, F. Leroy, C. Robyn \& P. Leleux. Karger, Basel.

Nimura, S. \& Ishida, K. (1976) Histochemical studies of $\Delta^{s}-3 \beta-, \quad 20 \alpha-$ and $20 \beta$-hydroxysteroid dehydrogenases and possible progestagen production in hamster eggs. J. Reprod. Fert. 48, 275-278.

Nose, K. \& Katsuta, H. (1975) Arrest of cultured rat liver cells in $\mathrm{G} 2$ phase by the treatment with dibutyryl cAMP. Biochem. Biophys. Res. Commun. 64, 983-988.

Notides, A.C., Hamilton, D.E. \& Rudolph, J.H. (1973) The action of a human protease on the estrogen receptor. Endocrinology 93, 210-216.

Noyes, R.W. \& Dickmann, Z. (1960) Relationship of ovular age to endometrial development. $J$. Reprod. Fert. 1, 186-196.

Noyes, R.W., Dickmann, Z., Doyle, L. \& Gates, A.H. (1963) Ovum transfers, synchronous and asynchronous in the study of implantation. In Delayed Implantation, pp. 197-211. Ed. A. C. Enders, University of Chicago Press.

Otten, J., Johnson, G.S. \& Pastan, I. (1972) Regulation of cell growth by cyclic adenosine $3^{\prime}, 5^{\prime}$ monophosphate. Effect of cell density and agents which alter cell growth on cyclic adenosine $3^{\prime}, 5^{\prime}$ monophosphate levels in fibroblasts. $J$. biol. Chem. 247, 7082-7087.

Owers, N.O. \& Blandau, R.J. (1971) Proteolytic activity of the rat and guinea pig blastocysts in vitro. In Biology of the Blastocyst, pp. 207-224. Ed. R. J. Blandau. University of Chicago Press.

Perry, J.S. \& Heap, R.B. (1973) Steroid synthesis by the pig blastocyst in vitro. Acta endocr., Copenh. 73, Suppl. 177, Abstr. 178.

Perry, J.S., Heap, R.B. \& Amoroso, E.C. (1973) Steroid hormone production by pig blastocysts. Nature, Lond. 245, 45-47.

Perry, J.S., Heap, R.B., Burton, R.D. \& Gadsby, J.E. (1976) Endocrinology of blastocyst and its role in the establishment of pregnancy. J. Repod. Fert., Suppl. 25, 85-104.

Pexton, J.S., Weems, C.W. \& Inskeep, E.K. (1975) Prostaglandin $\mathrm{F}$ in uterine venous plasma, ovarian arterial and venous plasma and in ovarian and luteal tissue of pregnant and nonpregnant ewes. J. Anim. Sci. 41, 154-159. 
Pinsker, M.C., Saceo, A.G. \& Mintz, B. (1974) Implantation-associated proteinase in mouse uterine fluids. Devl Biol. 38, 285-290.

Pratt, B.R., Butcher, R.L. \& Inskeep, E.K. (1977) Antiluteolytic effect of the conceptus and of PGE2 in ewes. J. Anim. Sci. 45, 784-791.

Psychoyos, A. (1960) La réaction déciduale est précédée de modifications précoses de la permeabilité capillaire de l'utérus. C. r. Séanc. Soc. Biol. 154, 1384 1387.

Psychoyos, A. (1966) Recent research on egg implantation. In Egg Implantation (Ciba Fndn Study Group No. 23), pp. 4-15. Eds G. E. Wolstenholme \& M. O'Connor. J. \& A. Churchill Ltd, London.

Psychoyos, A. (1973) Hormonal control of ovoimplantation. Vitams Horm. 31, 201-256.

Rankin, J.C., Ledford, B.E. \& Baggett, B. (1977) Early involvement of cyclic nucleotides in the artificially stimulated decidual cell reaction in the mouse uterus. Biol. Reprod. 17, 549-554.

Renard, J.-P. \& du Mesnil du Buisson, F. (1976) Culture and storage of cow embryos. Proc. 8th Int. Congr. Anim. Reprod. \& A.I., Krakow, Vol. 3, pp. 309-312.

Renfree, M.B. (1976) Embryonic diapause and delayed implantation in mammals. Biblphy Reprod. 28, 353358; 447-450.

Rinard, G.A. \& Chew, C.S. (1975) Uterine cyclic AMP: biphasic effect of estrogen on catecholamine sensitivity. Fedn Proc. Fedn Am. Socs exp. Biol. 34, 260, Abstr. 238.

Robertson, H.A. \& King, G.J. (1974) Plasma concentration of progesterone, oestrone, oestradiol-17\%, and of oestrone sulphate in the pig, at implantation, during pregnancy and at parturition. J. Reprod. Fert. 40, 133-141.

Robertson, H.A. \& King, G.J. (1975) Estrogen and placental attachment in the cow. J. Anim. Sci. 41, 377, Abstr.

Robertson, H.A. \& Sarda, I.R. (1971) A very early pregnancy test for mammals: its application to the cow, ewe and sow. J. Endocr. 49, 407-419.

Robertson, H.A., King, G.J. \& Carnegie, J.A. (1976) Oestrone sulphate and embryonic attachment in the cow, ewe and sow. Proc. 8th Int. Congr. Anim. Reprod. \& A.L., Krakow, Vol. 3, pp. 313-315.

Rosenfeld, M.G. \& Joshi, M.S. (1977) Possible role of a specific uterine fluid peptidase in implantation in the rat. J. Reprod. Fert. 51, 137-139.

Rosenfeld, M.G. \& O'Malley, B.W. (1970) Steroid hormones: effects on adenyl cyclase activity and adenosine $3^{\prime}, 5^{\prime}$ monophosphate in target tissues. Science, N.Y. 168, 253-255.

Rowson, L.E.A. \& Moor, R.M. (1966) Embryo transfer in the sheep; the significance of synchronizing oestrus in the donor and recipient animal. J. Reprod. Fert. 11, 207-212.

Rowson, L.E.A. \& Moor, R.M. (1967) The influence of embryonic tissue homogenate infused into the uterus on the lifespan of the corpus luteum of the sheep. $J$. Reprod. Fert. 13, 511-516.

Rowson, L.E.A., Lawson, R.A.S., Moor, R.M. \& Baker, A.A. (1972) Egg transfer in the cow: synchronization requirements. $J$. Reprod. Fert. 28, 427-431.

Saksena, S.K., Lau, I.F. \& Chang, M.C. (1976) Relationship between oestrogen, prostaglandin $F 2 \alpha$ and histamine in delayed implantation in the mouse. Acta endocr., Copenh. 81, 801-807.

Salomon, D.S. \& Sherman, M.I. (1975) The biosynthesis of progesterone by cultured mouse midgestational trophoblast cells. Devl Biol. 47, 394-406.

Samuel, C.A. (1971) The development of pig trophoblast at ectopic sites. J. Reprod. Fert. 27, 494-495.

Sananes, N., Baulieu, E.E. \& Le Goascogne, C. (1976) Prostaglandin as inducive factor of decidualization in the rat uterus. Molec. cell. Endocr. 6, 153-158.

Sanbourn, B.M., Bhalla, R.C. \& Korenman, S.G. (1973) Use of a modified radioligand assay to measure the effect of estradiol on uterine adenosine $3^{\prime}, 5^{\prime}$-cyclic monophosphate. Endocrinology 92, 494-499.

Sarda, I.R., Robertson, H.A. \& Smeaton, T.C. (1973) Sequential changes in plasma progesterone levels in the ewe during the estrous cycle and during pregnancy in intact and ovariectomized sheep. Can. $J$. Anim. Sci. 53, 25-34.

Saxena, B.B., Hasan, S.H., Haour, F. \& SchmidtGollwitzer, M. (1974) Radioreceptor assay of human chorionic gonadotrophin: detection of early pregnancy. Science, N.Y. 184, 793-795.

Seamark, R.F. \& Lutwak-Mann, C. (1972) Progestins in rabbit blastocysts. J. Reprod. Fert. 29, 147-148.

Sen Gupta, J., Dey, S.K. \& Dickmann, Z. (1977) Evidence that "embryonic estrogen" is a factor which controls development of mouse preimplantation embryo. Steroids 29, 363-369.

Shelesnyak, M.C. (1954) The action of selected drugs on deciduoma formation. Endocrinology 55, 85-89.

Shelesnyak, M.C. (1957) Some experimental studies on the mechanism of ova-implantation in the rat. Recent Prog. Horm. Res. 13, 269-322.

Shelesnyak, M.C. (1960) Nidation of the fertilized ovum. Endeavour 19, 81-86.

Shelesnyak, M.C. \& Kraicer, P.F. (1963) The role of oestrogen in nidation. In Delayed Implantation, pp. 265-279. Ed. A. C. Enders. University of Chicago Press.

Shemesh, M., Ayalon, N. \& Lindner, H.R. (1968) Early effect of conceptus on plasma progesterone levels in the cow. J. Reprod. Fert. 15, 161-164.

Shemesh, M., Milaguir, F., Ayalon, N. \& Hansel, W. (1979) Steroidogenesis and prostaglandin synthesis by cultured bovine blastocyst. J. Reprod. Fert. 56, $181-185$

Sherman, M.I. \& Atienza, S.B. (1977) Production and metabolism of progesterone and androstenedione by cultured mouse blastocysts. Biol. Reprod. 16, 190199.

Simantov, R. \& Sachs, L. (1975) Temperature sensitivity of cyclic adenosine $3^{\prime}: 5^{\prime}$-monophosphate-binding proteins and the regulation of growth and differentiation in neuroblastoma cells. J. biol. Chem. 250, 3236-3242.

Singh, M.M. \& Adams, C.E. (1978) Luteotrophic effect of the rabbit blastocyst. J. Reprod. Fert. 53, 331333.

Singh, M. M. \& Booth, W.D. (1978) Studies on the metabolism of neutral steroids by preimplantation rabbit blastocysts in vitro and the origin of blastocyst oestrogen. J. Reprod. Fert. 53, 297-304.

Singhal, R.L., Tsang, B.K. \& Sutherland, D.J.B. (1976) Regulation of cyclic nucleotide and prostaglandin 
metabolism in sex steroid dependent cells. In Advances in Sex Hormone Research, Vol. 2, Cellular mechanisms modulating gonadal hormone action, pp. 325-424. Eds R. L. Singhal \& J. A. Thomas. H. M. \& M., Aylesbury, England.

Smith, D.M. (1968) The effect on implantation of treating cultured mouse blastocysts with oestrogen in vitro and the uptake of $3(\mathrm{H})$ oestradiol by blastocysts. J. Endocr. 41, 17-29.

Smith, D.M. \& Smith, A.E.S. (1971) Uptake and incorporation of amino acids by cultured mouse embryos: estrogen stimulation. Biol. Reprod. 4, 6673.

Stabenfeldt, G.H., Drost, M. \& Franti, C.E. (1972) Peripheral plasma progesterone levels in the ewe during pregnancy and parturition. Endocrinology 90, 144-150.

Staples, L.D., Lawson, R.A.S., Cerini, M., Sheers, M. \& Findlay, J.K. (1976) Production and characterisation of antisera to pregnancy specific antigens in the sheep, cow and pig. Theriogenology 6, 627.

Stone, S.L. \& Hamner, C.E. (1977) Hormonal and regional influences of the oviduct on the development of rabbit embryos. Biol. Reprod. 16, 638-646.

Stone, S.L., Richardson, L.L., Hamner, C.E. \& Oliphant, G. (1977) Partial characterisation of hormonemediated inhibition of embryo development in rabbit oviduct fluid. Biol. Reprod. 16, 647-653.

Sundaram, K., Connell, K.G. \& Passantino, T. (1975) Implication of absence of HCG-like gonadotrophin in the blastocyst for control of corpus luteum function in pregnant rabbit. Nature, Lond. 256, 739741.

Surani, M.A.H. (1975) Hormonal regulation of proteins in the uterine secretions of ovariectomized rats and the implications for implantation and embryonic diapause. J. Reprod. Fert. 43, 411-417.

Surani, M.A.H. (1977) Response of pre-implantation rat blastocysts in vitro to extra-cellular uterine luminal components, serum and hormones. J. Cell Sci. 25, 265-277.

Surani, M.A.H. \& Webb, F.T.G. (1977) Effect of dibutyryl cyclic AMP and oestradiol on incorporation of $\left[{ }^{3} \mathrm{H}\right]$ leucine into the proteins of luminal fluid of the rat uterus. J. Endocr. 74, 431-439.

Sutherland, E.W., Butcher, R.W., Robison, G.A. \& Hardman, J.G. (1967) The role of adenosine 3',5'monophosphate in hormone action. In Wirkungmechanismen der Hormone, 18 colloquium der Gesellschaft für Physiologische Chemie, pp. 1-32. Ed. P. Karlson. Springer Verlag, Berlin.

Swift, A.D. \& O'Grady, J.E. (1976) Uterine cyclic AMP in early pregnancy in the rat. $J$. Endocr. 68, 35P$36 P$.

Szego, C.M. \& Davies, J.S. (1967) Adenosine $3^{\prime}, 5^{\prime}$ monophosphate in rat uterus: acute elevation by estrogen. Proc. natn. Acad. Sci. U.S.A. 58, 17111718.

Tachi, C., Tachi, S. \& Lindner, H.R. (1970) Action of antihistamines on the endometrium and the histamine theory of decidual induction. J. Reprod. Fert. 23, 169-172.

Tervit, H.R., Whittingham, G. \& Rowson, L.E.A. (1972) Successful culture in vitro of sheep and cattle ova. $J$. Reprod. Fert. 30, 493-497.
Thorburn, G.D., Cox, R.I., Currie, W.B., Restall, B.J. \& Schneider, W. (1973) PGF and progesterone concentrations in the utero-ovarian venous plasma of the ewe during the oestrous cycle and early pregnancy. J. Reprod. Fert., Suppl. 18, 151158.

Tobert, J.A. (1976) A study of the possible role of prostaglandins in decidualization using a nonsurgical method for the installation of fluids into the rat uterine lumen. J. Reprod. Fert. 47, 391-393.

Van der Wiel, D.F.M. \& Everts, H. (1977) Oestrone and oestrone sulphate in the blastocyst uterus mucosa and uterine blood at day 14 of pregnancy in the pig. Acta endocr., Copenh. 85, Suppl. 212, p. 130. Abstr. No. 207.

Vane, J.R. (1976) Prostaglandins for mediators of inflammation. Adv. Prostaglandin and Thromboxane Res. 2, 791-801.

Warner, C.M. \& Tollefson, C.M. (1977) Effect of estradiol on RNA synthesis in preimplantation mouse embryos cultured in vitro. Biol. Reprod. 16, $627-632$.

Watson, J., Anderson, F.B., Alam, M., O'Grady, J.E. \& Heald, P.J. (1975) Plasma hormones and pituitary luteinizing hormone in the rat during the early stages of pregnancy and after post-coital treatment with tamoxifen. J. Endocr. 65, 7-17.

Webb, F.T.G. (1975a) The inability of dibutyryl adenosine $3^{\prime}, 5^{\prime}$-monophosphate to induce the decidual reaction in intact pseudopregnant mice. $J$. Reprod. Fert. 42, 187-188.

Webb, F.T.G. (1975b) Implantation in ovariectomized mice treated with dibutyryl adenosine $3^{\prime}, 5^{\prime}$-monophosphate (dibutyryl cyclic AMP). J. Reprod. Fert. 42, 511-517.

Webb, F.T.G. (1977) Cyclic AMP and the preparation of the mouse uterus for implantation. $J$. Reprod. Fert. 50, 83-89.

Weitlauf, H.M. (1976) Effect of uterine flushings on RNA synthesis by "implanting" and "delayed implanting" mouse blastocysts, in vitro. Biol. Reprod. 14, 566-571.

Whitten, W.K. (1971) "Nutrient requirements for the culture of preimplantation embryos in vitro." $A d v$. Biosci. 6, 129-139.

Whittingham, D.G. (1971) Culture of mouse ova. $J$. Reprod. Fert., Suppl. 14, 7-21.

Wide, L. (1969) Early diagnosis of pregnancy. Lancet ii, 863-864.

Wiley, L.D. (1974) Presence of a gonadotrophin on the surface of preimplanted mouse embryos. Nature, Lond. 252, 715-716.

Wilson, L., Jr, Butcher, R.L. \& Inskeep, E.K. (1970) Studies of the relation of the decidual cell response to luteal maintenance in the pseudopregnant rat. Biol. Reprod. 3, 342-346.

Wilson, L., Jr, Butcher, R.L. \& Inskeep, E.K. (1972) Prostaglandin F2 $\alpha$ in the uterus of ewes during early pregnancy. Prostaglandins 1, 479-482.

Wimsatt, W.A. (1975) Some comparative aspects of implantation. Biol. Reprod. 12, 1-40.

Wislocki, G.B. \& Bennett, H.S. (1943) The histology and cytology of the human and monkey placenta with special reference to the trophoblast. Am. J. Anat. 73, 335-449. 
Wu, J.T. \& Chang, M.C. (1977) Failure of dibutyryl cyclic AMP to induce implantation in rats and mice. Biol. Reprod. 17, 355-360.

Wu, J.T. \& Meyer, R.K. (1970) The effect on implantation of culturing delayed rabbit blastocysts in medium containing 17ß-estradiol. Biol. Reprod. 3, 201-204.
Yochim, J.M. (1975) Development of the progestational uterus: metabolic aspects. Biol. Reprod. 12, 106-133.

Zor, U., Koch, Y., Lamprecht, S.A., Ausher, J. \& Lindner, H.R. (1973) Mechanism of oestradiol action on the rat uterus: independance of cyclic AMP, prostaglandin E2 and $\beta$-adrenergic mediation. J. Endocr. 58, 525-533. 